\title{
13. SILICA DIAGENESIS AND ITS EFFECTS ON LITHIFICATION OF BROKEN RIDGE DEPOSITS, CENTRAL INDIAN OCEAN ${ }^{1}$
}

\author{
Ralf Littke, ${ }^{2}$ Elisabeth Fourtanier, ${ }^{3}$ Jürgen Thurow, ${ }^{4}$ and Elliott Taylor ${ }^{5}$
}

\begin{abstract}
Within a dipping sequence of middle Cretaceous to Eocene sediments on Broken Ridge, opal-A, opal-CT, and quartz occur as minor constituents in carbonate and ash-rich sediments. Biogenic opal-A is mainly derived from diatoms and radiolarians. Opal-A and almost all siliceous microfossils disappear within a narrow $(<20$-m-thick) transition zone below which authigenic opal-CT and quartz are present. These latter silica polymorphs occur together within a 750 -m-thick interval, but the ratio of quartz/opal-CT increases with increasing age and depth within the pre-rift sediment sequence. The boundary between opal-A- and opal-CT-bearing sediments is also a physical boundary at which density, $P$-wave velocity, and acoustic impedance change. This physical transition is probably caused by infilling of pore space by opal-CT lepispheres.
\end{abstract}

\section{INTRODUCTION}

Hydrous silica is a common constituent in young marine sediments and is derived from biogenic opal-A present as the skeletal remains of diatoms, radiolarians, and siliceous sponges. During diagenesis, opal-A is dissolved and partly reprecipitated as metastable, poorly ordered interlayered tridymite and cristobalite (opal-CT; Jones and Segnit, 1971; Langer and Flörke, 1974). Opal-CT crystal ordering and subsequent dissolution (Murata et al., 1977) results in transformation to quartz (see Murata et al., 1977; von Rad et al., 1977; Thurow, 1988). In marine sediments, another-though less well-accepted-source for opal-CT and quartz is volcanic ash, which may also undergo recrystallization during diagenesis. Opal-A, opal-CT, and authigenic quartz occur as minor constituents in many marine, clay-rich sediments and in carbonates. The objectives of our study are to document the authigenic silica phases found in the calcite-rich ( $80 \%$ and less) sediments on Broken Ridge and to provide evidence for their origin.

Drilling at Sites 752 through 755 on Broken Ridge (Fig. 1) penetrated a sequence of Neogene, Paleogene, and Upper Cretaceous post-rift and pre-rift sediments that are mainly composed of nannofossil and foraminifer ooze, chalk, and limestone (Peirce, Weissel, et al., 1989). As a result of the rifting-related uplift and erosion of Broken Ridge during the late Eocene, pre-rift sediments are presently not at their maximum burial depth. A goal of this research project was to evaluate whether the occurrence of authigenic silica at Broken Ridge is related to the present burial depth because dissolution of biogenic silica is a presently ongoing process or whether, alternatively, the degree of silica diagenesis is related to the presumably greater pre-rift burial depth.

\footnotetext{
${ }^{1}$ Weissel, J., Peirce, J., Taylor, E., Alt, J., et al., 1991. Proc. ODP, Sci. Results, 121: College Station, TX (Ocean Drilling Program).

${ }^{2}$ Forschungszentrum Jülich GmbH (KFA), Institut für Erdöl und Organische Geochemie, Postfach 19 13, D-5170 Jülich, F.R.G.

${ }^{3}$ Lab. d'Hydrologie et de Géochemie Isotopique, Université Paris-Sud, 91405 , Orsay, France. (Present address: U. S. Geological Survey, MS 915, Menlo Park, CA 94025, U.S.A.)

${ }^{4}$ Universität Tübingen, Institut und Museum für Geologie und Paläontologie, Sigwartstr. 10, D-7400 Tübingen, F.R.G.

${ }^{3}$ Woodward-Clyde Consultants, 3440 Bank of California Bldg., 900 Fourth Ave., Seattle, WA 98164, U.S.A.
}

Other questions addressed here are (1) what is the thickness and character of the transition zone between opal-A-bearing sediments with well-preserved siliceous fossils and opal-CT-bearing sediments, and (2) to what extent does the diagenetic silica transformation have an effect on physical properties (e.g., on sediment density). It has been previously shown at other locations that silica-cemented rocks show higher densities and may even be traced as seismic reflectors over large areas (e.g., Hein et al., 1978).

\section{METHODS}

$\mathrm{X}$-ray diffraction (XRD) was performed aboard the JOIDES Resolution using a Philips ADP 3520 diffractometer under conditions described in Peirce, Weissel, et al. (1989). Shore-based measurements were made with a STOE powder diffraction system. Some of the samples used for these measurements were leached with hydrochloric acid. X-ray fluorescence was performed for major elements using established procedures (e.g., Peirce, Weissel, et al., 1989) on decarbonized samples.

For transmitted light studies, sediments were boiled in $\mathrm{HCl}$ and $\mathrm{H}_{2} \mathrm{O}_{2}$. Residues free of carbonate and organic matter were diluted with distilled water in beakers. A small volume of the resulting suspension was sampled and deposited on a cover slide, dried, and then mounted in Hyrax. The prepared slides were used to qualitatively assess the siliceous fraction of the sediment including siliceous microfossils, clay minerals, ash, and other constituents. The slides do not provide accurate quantitative ratios of the different silica components because the larger and heavier fragments (e.g., ashes and large radiolarians) may have settled prior to sampling the suspension and might therefore be underrepresented. Microscope observations were made in transmitted light at high magnification $(\times 1250)$. SEM studies and EDAX analyses were performed on whole-rock pieces as well as on silica concentrates. Physical-properties analyses used herein were performed aboard the JOIDES Resolution. Methods used for analyses of bulk density and compressional-wave velocity are described in Peirce, Weissel, et al. (1989).

\section{RESULTS}

\section{X-Ray Mineralogy of Silica on Broken Ridge}

Three silica phases were detected by XRD analyses of Broken Ridge sediments: opal-A, opal-CT, and quartz (following the 


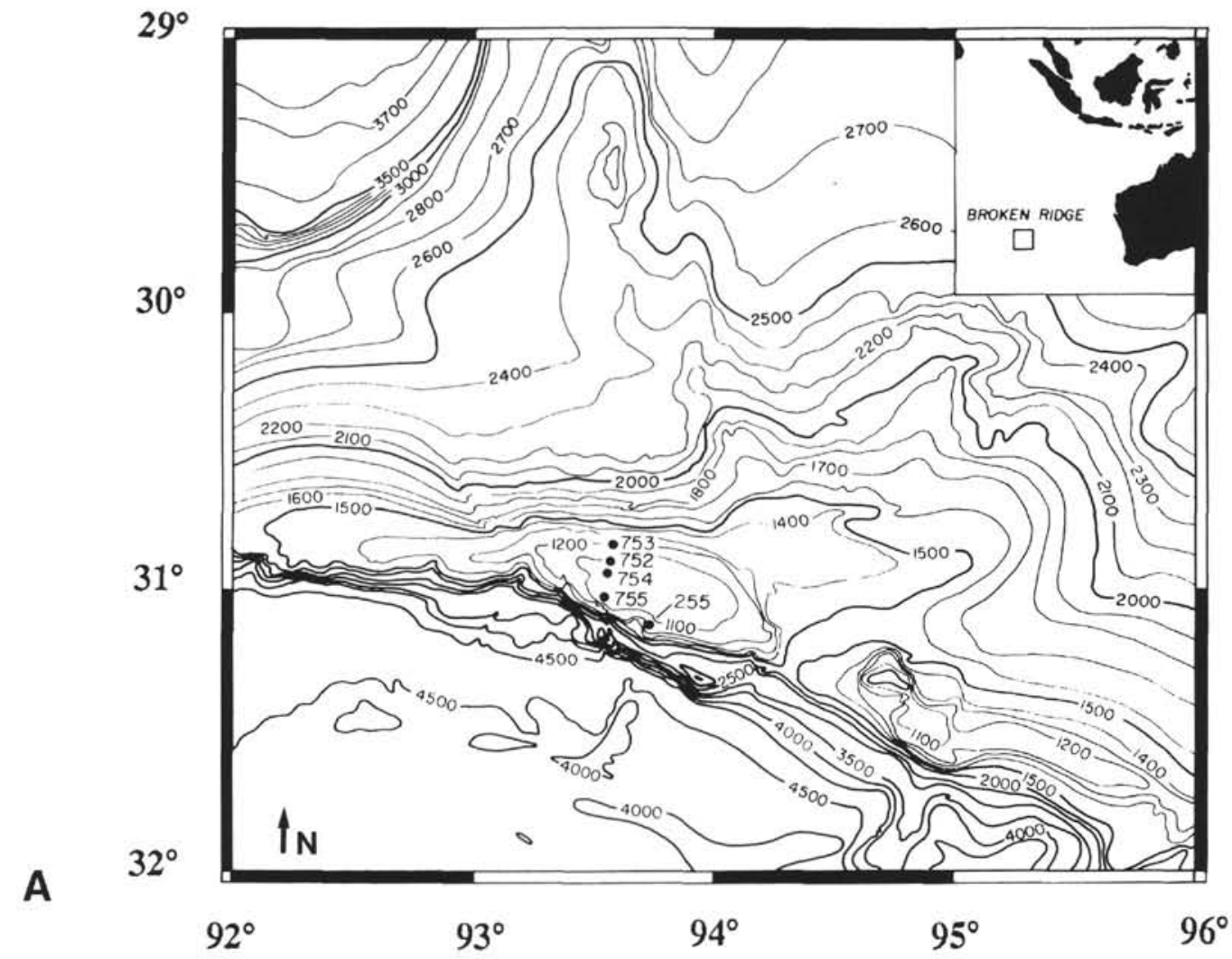

Figure 1. Broken Ridge. A. Bathymetry and locations of ODP Leg 121 and DSDP Leg 26 drill sites. B. North-south single-channel seismic reflection profile of Broken Ridge with location of Sites 752, 753, 754, and 755 and lithology and stratigraphic columns. Note that the Neogene horizontal reflectors discordantly overlie Paleogene and older strata. Units A-E at Site 752 designate specific physical properties units discussed in the text.

terminology of Jones and Segnit, 1971). Opal-A is characterized by a broad intensity hump between 2.7 and $5.9 \AA$ with a maximum at $4.0 \AA$. One typical example for this pattern is shown in Figure 2A. Opal-A is the predominant silica form in sediments from depths between 114 and $278 \mathrm{~m}$ below seafloor (mbsf) at Site 752, in the lower Eocene through upper Paleocene section (Table 1). Below this interval, only one sample from 289 mbsf displayed an opal-A signal. This latter sample revealed a slightly narrower hump than that found in the sediments above (Fig. 2B) and also showed a second hump at $2.55 \AA$ (see Hein et al., 1978), which generally becomes more pronounced at the opal-CT stage.

The youngest occurrence of opal-CT is at $281 \mathrm{mbsf}$ in Hole 752B (Table 1). X-ray peaks are typically at 4.12 and $4.34 \AA$ at this level (Fig. 2C). At greater depth and in older samples drilled at Site 754 , slightly lower lattice spacings were found, such as 4.03 and $4.28 \AA$ in a sample from 316 mbsf at Site 754 (Fig. 2D). This is the oldest sample on Broken Ridge in which opal-CT diffraction patterns dominate the silica signal. In the deepest ( 345 mbsf) sample at Site 754 and in Santonian and older sediments at Site 755, quartz is the most abundant silica polymorph (Fig. 2E).

\section{Elemental Composition of Carbonate-Free Residues}

The elemental composition of carbonate-free residues was measured in order to gain some insight as to the source of silica in sediments on Broken Ridge. Authigenic opal-CT and quartz are most likely derived from either recrystallization of biogenic silica (opal-A) or from devitrification of volcanic glass (Calvert, 1974). The first process has been much better documented in the past (e.g., Hein et al., 1978) than the second process. Both opal-A and volcanic glass are present in Broken Ridge sediments, but are usually subordinate to calcite. Ash is the major constituent of sediments only in some of the oldest deposits drilled at Site 755 (Peirce, Weissel, et al., 1989).

In order to distinguish between biogenic and nonbiogenic silica, an empirical formula was used (Leinen, 1977):

$$
4.33 \mathrm{Al}+1.35 \mathrm{Mg}^{2}=\text { nonbiogenic silica. }
$$

This formula is based on the fact that biogenic silica consists of pure $\mathrm{SiO}_{2}$ with an average of less than $0.1 \%$ of other elements (Martin and Knauer, 1973). Therefore, residues that contain opalCT or quartz derived from a biogenic source should be rich in $\mathrm{SiO}_{2}$ if the authigenic silica is a major constituent of the residue.

As shown in Table $2, \mathrm{SiO}_{2}$ contents in the selected residues vary between $71 \%$ and $99 \%$. Next in quantity are $\mathrm{Al}_{2} \mathrm{O}_{3}, \mathrm{Fe}_{2} \mathrm{O}_{3}$, $\mathrm{MgO}, \mathrm{CaO}, \mathrm{K}_{2} \mathrm{O}$, and $\mathrm{TiO}_{2}$. Calculated contents of nonbiogenic silica are $3 \%$ to $32 \%$, whereas percentages of biogenic silica vary between $40 \%$ and $95 \%$ (Table 3 ).

The calculated amount of nonbiogenic silica may be present both as authigenic $\mathrm{SiO}_{2}$-phase (opal-CT or quartz) derived from devitrification of volcanic glass and as hydrous silicate (zeolites) and clay minerals (smectite). According to X-ray data, clay minerals are most abundant in the residues containing only $71 \%-76 \%$ $\mathrm{SiO}_{2}$ (Samples 121-752A-25X-1, 53-55 cm, 121-754B-5R-2, $12-14 \mathrm{~cm}, 121-754 \mathrm{~A}-20 \mathrm{~N}-2,120-123 \mathrm{~cm}$, and 121-755A-14R-2, 137-139 cm; compare Tables 2 and 3).

\section{Preservation of Siliceous Microfossils}

The preservation of siliceous microfossils was studied in detail for samples obtained between 200 and 304 mbsf at Site 752, which is the sequence characterized by the transition from opal-A to opal-CT (Table 1). Siliceous microfossil assemblages are present 


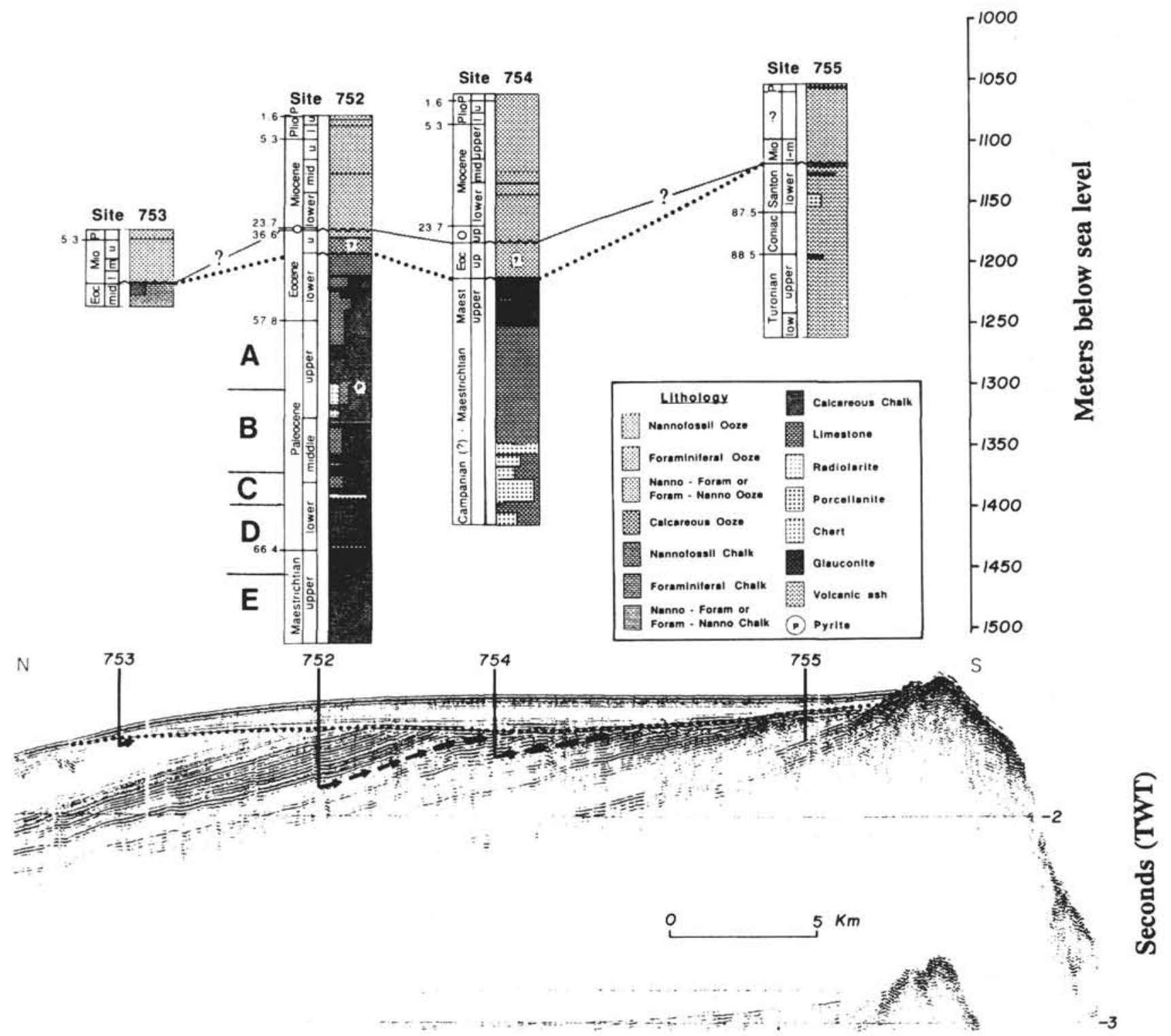

Figure 1 (continued).

in the lower Eocene and upper Paleocene sediments of Site 752. The assemblages are composed predominantly of diatoms and radiolarians, but also of silicoflagellates, sponge spicules, and ebridians (Fourtanier, this volume). Closely spaced samples (average 1-m spacing) were taken between 268 and 304 mbsf and results are synthesized in Table 4 . Some of the different stages of preservation of the biological remains are illustrated on Plates 1 and 2.

Preservation is considered "good" where delicate diatom species such as Hemiaulus are preserved in the residues. Usually, diatoms are diverse in such samples (Pl. 1, Fig. 1). Little dissolution and fragmentation are, however, already obvious in some of the better preserved residues. Preservation is considered "moderate" when the assemblage is intensively broken and dissolved but moderately resistant species are present. Delicate species (e.g., Hemiaulus) are not present or are strongly etched. Preservation is considered "poor" when only the coarse and heavily silicified diatoms are present (e.g., Stephanopyxis, Pl. 1, Fig. 2). Samples which do not contain diatoms are reported as barren, and also contain few radiolarians that are generally more resistant to dissolution.

Estimating the preservation of a diatom assemblage is somewhat subjective. We tried to quantify preservation using a fragmentation index defined as the ratio of whole diatoms/diatom fragments $\times 100$. Diatoms are considered whole when at least one-half of the diatom valve is present. Fragments are counted only if they are larger than 10 microns $(\mu \mathrm{m})$. Two hundred specimens per sample were counted using this method. We selected this method for estimating the degree of biogenic silica preservation or transformation because the "first indication of structure dissolution is the breaking up of the central part from the diatom valve" (Mann and Müller, 1985); that is, dissolution may be accompanied by fragmentation, and "the degree of fragmentation of a diatom assemblage is seemingly tightly connected with the degree of dissolution" (Mikkelsen, 1980; see also Williams et al., 1985).

The ratio "whole diatom/diatom fragments" usually correlates well with the preservation stage of the diatom assemblages. At 


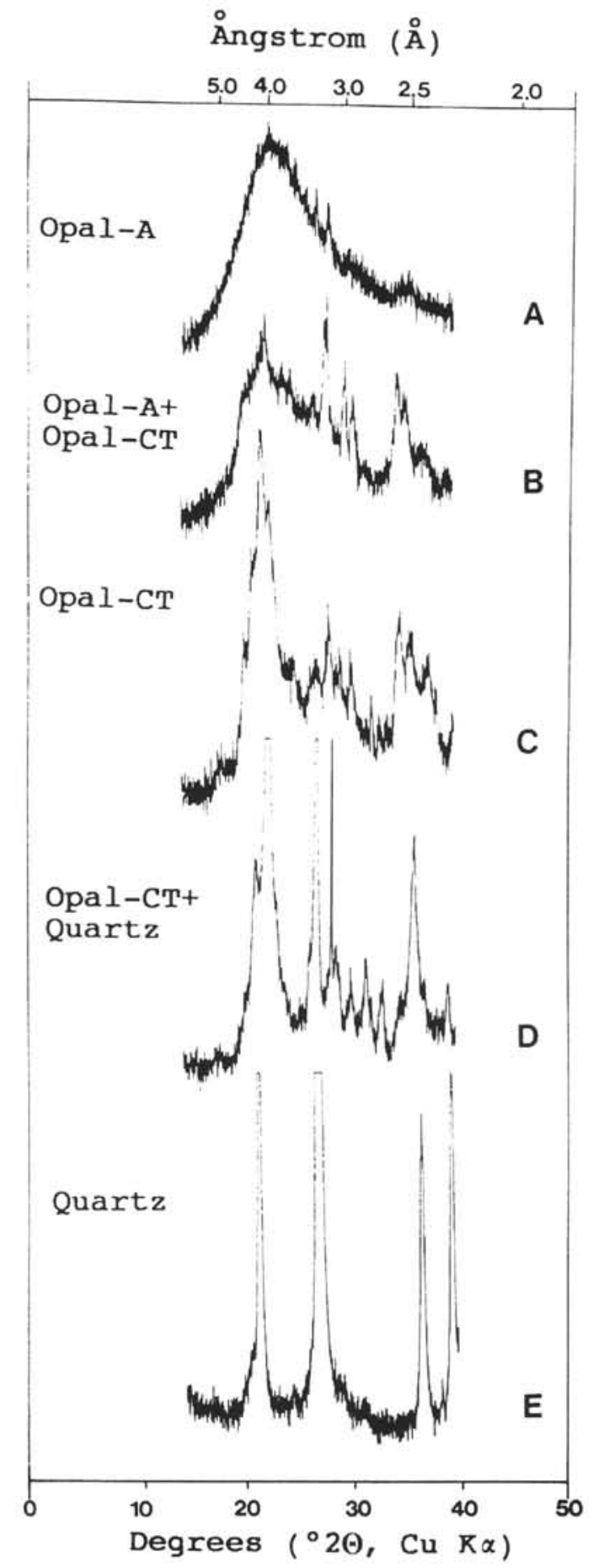

Figure 2. X-ray diffractograms of Leg 121 samples. A. Sample 121-752A$15 \mathrm{X}-1,55-57 \mathrm{~cm}$. B. Sample 121-752A-32X-1, 55-57 cm. C. Sample 121752A-31X-1, 55-57 cm. D. Sample 121-754B-22R-1, 21-23 cm. E. Sample 121-755A-14R-2, 137-139 cm.

Hole $752 \mathrm{~A}$, the ratio indexes range generally between 5 and 20 for moderately to well-preserved assemblages and between 1 and 5 for poorly preserved assemblages. These ratios, however, do not exactly reflect the preservation: smaller ratios in well-preserved assemblages (e.g., Sample 121-752A-23X-1, 44-46 cm) are explained by the occurrence of numerous fragments of delicate species that are not found in more dissolved assemblages. Rela- tively high ratios also occur in poorly preserved samples (e.g., Sample 121-752A-29X-1, 55-57 cm) where assemblages are dominated by Stephanopyxis, a diatom relatively resistant to dissolution and fragmentation. As a result, the ratio "whole diatoms/fragments" is only partially satisfactory as a preservation index of a diatom assemblage.

The dissolution of siliceous remains is very pronounced at depths below $296 \mathrm{mbsf}$ at Site 752 . Some samples are barren of recognizable diatoms but contain rounded siliceous structures that preserved some biological patterns (e.g., pores). Other samples do not contain any remains with biological patterns but only rounded siliceous structures. The ratio "diatoms/diatoms + radiolarians" (Table 4) probably underestimates the radiolarians for reasons discussed in the "Methods" section. However, it is obvious that diatoms do dominate most of the residues. As previous studies suggested (e.g., Mikkelsen, 1980), radiolarians are the group of siliceous microfossils most resistant to dissolution. Thus, we expected the ratio "diatoms/diatoms + radiolarians" to correlate with the preservation (Table 4). However, such a correlation is not obvious.

Nonbiogenic siliceous components include clay minerals and ash. Clay minerals were not detected in the prepared slides and probably occur only in small amounts. Only fine-grained ash is present in slides, but larger-sized, dark-colored ash was observed in the processed residues.

In the opal-A barren intervals, authigenic silica consists of opal-CT blades (Pl. 1, Fig. 4) and lepispheres (P1. 2, Figs. 3 and 4). Part of the authigenic silica seems to occur where diatoms were originally located (Pl. 1, Fig. 3), although biogenic structures cannot be recognized clearly. In addition to opal-CT, authigenic phillipsite (Pl. 1, Fig. 5, and Pl. 2, Fig. 4) and clay minerals (smectite?, Pl. 2, Fig. 2) were found. Furthermore, micrite formation proves that carbonate recrystallization occurred (Pl. 2, Fig. $1)$.

\section{Physical Properties and Geophysical Logging}

The physical properties aspect of the stratigraphic sections of Sites 752 and 754 can be subdivided into five units (A-E; see Fig. 1B). Three distinct intervals mark the progressive diagenesis within the calcareous sections (Units A, D, and E). An opal-A-rich interval (Unit B) disrupts the otherwise continuous trend of downhole consolidation and density increase within the calcareous sequence. A thin transitional section (Unit C) separates the opalA-rich sediments from the calcareous section below.

The uppermost 100 m of sediment at Site 752 (Fig. 1B) consists of unconsolidated carbonate ooze with nearly constant density, porosity, and velocity values regardless of depth. The bulk density of this cap sequence ranges from 1.52 to $1.75 \mathrm{~g} / \mathrm{cm}^{3}$ (Fig. 3) and the mean porosity of the section, corrected for rebound (Hamilton, 1976 ), is $66 \%$. These values reflect a slightly more compacted state relative to other pelagic calcareous oozes (Mahmood, 1990).

The first major downhole contrast in physical properties occurs across the angular unconformity (100 mbsf at Site 752$)$. The calcareous sediments below the unconformity are indurated, forming chalk (Unit A). The original transition from ooze to chalk may have been much more subtle; however, erosional truncation of previous strata during the middle Eocene uplift of Broken Ridge removed the overburden that consolidated the underlying section. Bulk densities of the chalk in Unit A range from 1.67 to $2.05 \mathrm{~g} / \mathrm{cm}^{3}$.

Increased amounts of biogenic silica (opal-A) occur in the calcareous section below 220 mbsf at Site 752 . The open, porous framework of diatoms and radiolarians within the carbonates gives rise to the higher mean porosity $(54 \%)$ and lower mean grain density $\left(2.60 \mathrm{~g} / \mathrm{cm}^{3}\right)$ within Unit B. The approximately $60-\mathrm{m}$ thick interval shows progressive downhole consolidation, the 
Table 1. Silica phases in selected samples (carbonate-free residues), Broken Ridge.

\begin{tabular}{|c|c|c|c|c|c|}
\hline $\begin{array}{l}\text { Core, section, } \\
\text { interval }(\mathrm{cm})\end{array}$ & $\begin{array}{l}\text { Depth } \\
\text { (mbsf) }\end{array}$ & Age & $\begin{array}{l}\text { Major } \\
\text { silica } \\
\text { phase }\end{array}$ & $\begin{array}{l}\text { Minor } \\
\text { silica } \\
\text { phase }\end{array}$ & $\begin{array}{c}\text { Calcite } \\
(\%)\end{array}$ \\
\hline \multicolumn{6}{|l|}{$121-752 \mathrm{~A}-$} \\
\hline $13 \mathrm{X}-1,55-57$ & 113 & Eocene & opal-A & & 99 \\
\hline $14 X-1,55-57$ & 124 & Eocene & opal-A & & 85 \\
\hline $15 \mathrm{X}-1,55-57$ & 133 & Eocene & opal-A & & 86 \\
\hline $16 \mathrm{X}-1,55-57$ & 143 & Eocene & opal-A & & 96 \\
\hline $17 \mathrm{X}-1,55-57$ & 152 & Eocene & opal-A & & 84 \\
\hline $18 \mathrm{X}-1,55-57$ & 162 & Eocene & opal-A & & 86 \\
\hline $19 X-1,55-57$ & 172 & late Paleocene & opal-A & & 90 \\
\hline $20 \mathrm{X}-1,55-57$ & 181 & late Paleocene & opal-A & & 86 \\
\hline $21 X-1,55-57$ & 191 & late Paleocene & opal-A & & 92 \\
\hline $22 \mathrm{X}-1,55-57$ & 201 & late Paleocene & opal-A & & 90 \\
\hline $23 \mathrm{X}-1,44-46$ & 211 & late Paleocene & opal-A & & 87 \\
\hline $25 \mathrm{X}-1,53-55$ & 220 & late Paleocene & opal-A & quartz & 76 \\
\hline $26 \mathrm{X}-1,55-57$ & 240 & late Paleocene & opal-A & & 68 \\
\hline $27 \mathrm{X}-1,50-52$ & 249 & late Paleocene & opal-A & & 75 \\
\hline $28 \mathrm{X}-1,55-57$ & 259 & late Paleocene & opal-A & & 85 \\
\hline $29 \mathrm{X}-1,55-57$ & 269 & late Paleocene & opal-A & & 74 \\
\hline $30 \mathrm{X}-1,55-57$ & 278 & late Paleocene & opal-A & & 91 \\
\hline $31 X-1,55-57$ & 281 & late Paleocene & opal-CT & & 85 \\
\hline $32 X-1,55-57$ & 289 & late Paleocene & opal-A & & 82 \\
\hline $33 \mathrm{X}-1,55-57$ & 299 & early Paleocene & opal-CT & & 79 \\
\hline \multicolumn{6}{|l|}{$121-752 \mathrm{~B}-$} \\
\hline $8 R-4,89-91$ & 331 & early Paleocene & opal-CT & & 64 \\
\hline $10 \mathrm{R}-4,69-71$ & 350 & early Paleocene & opal-CT & quartz & 74 \\
\hline $11 \mathrm{R}-2,88-90$ & 358 & early Paleocene & opal-CT & & 20 \\
\hline $12 \mathrm{R}-6,87-89$ & 373 & late Maestrichtian & quartz & & 53 \\
\hline $13 R-3,10-12$ & 378 & late Maestrichtian & opal-CT & quartz & 68 \\
\hline $13 R-5,77-79$ & 381 & late Maestrichtian & quartz & & 65 \\
\hline \multicolumn{6}{|l|}{ 121-754B- } \\
\hline $5 R-1,65-67$ & 152 & early Maestrichtian & opal-CT & & 2 \\
\hline $5 R-2,12-14$ & 153 & early Maestrichtian & opal-CT & & 44 \\
\hline \multicolumn{6}{|l|}{$121-754 \mathrm{~A}-$} \\
\hline $19 \mathrm{~N}-1,54-55$ & 160 & Campanian (?) & opal-CT & quartz & 65 \\
\hline $20 \mathrm{~N}-2,89-91$ & 164 & Campanian (?) & opal-CT & quartz & 82 \\
\hline $20 \mathrm{~N}-2,120-123$ & 165 & Campanian (?) & quartz & & 28 \\
\hline $23 \mathrm{~N}-1,21-23$ & 171 & Campanian (?) & quartz & & 0.5 \\
\hline \multicolumn{6}{|l|}{$121-754 \mathrm{~B}-$} \\
\hline $9 R-4,81-83$ & 195 & Campanian (?) & opal-CT & quartz & 79 \\
\hline $9 R-6,82-84$ & 198 & Campanian (?) & quartz & & 44 \\
\hline $14 \mathrm{R}-6,87-89$ & 247 & Campanian (?) & opal-CT & quartz & 44 \\
\hline $15 \mathrm{R}-2,92-94$ & 250 & Campanian (?) & opal-CT & quartz & 77 \\
\hline $19 \mathrm{R}-1,92-94$ & 288 & Campanian (?) & quartz & & 59 \\
\hline $20 \mathrm{R}-1,44-46$ & 297 & Campanian (?) & opal-CT & quartz & 32 \\
\hline $22 \mathrm{R}-1,21-23$ & 316 & Campanian (?) & opal-CT & quartz & 63 \\
\hline $25 \mathrm{R}-1,18-20$ & 345 & Campanian (?) & quartz & & 80 \\
\hline \multicolumn{6}{|l|}{$121-755 \mathrm{~A}-$} \\
\hline $9 \mathrm{R}-2,80-82$ & 103 & Santonian-Coniacian & quartz & & 20 \\
\hline $12 \mathrm{R}-1,82-84$ & 132 & Coniacian-Turonian & quartz & opal-CT & 14 \\
\hline $14 \mathrm{R}-2,137-139$ & 153 & Coniacian-Turonian & quartz & opal-CT & 8 \\
\hline $18 \mathrm{R}-2,11-13$ & 191 & Coniacian-Turonian & quartz & opal-CT & 44 \\
\hline
\end{tabular}

Note: Prerift depths for samples older than late Eocene can be calculated by adding 100 , 400 , and $1000 \mathrm{~m}$ to present sub-bottom depths at Sites 752,754 , and 755 , respectively.

base of which marks the top of the transitional Unit C at $290 \mathrm{mbsf}$ (Figs. 1B and 3D).

A marked jump in sediment density, compressional-wave velocity, and acoustic impedance occurs at about 290 mbsf at Site 752 (Fig. 3; Peirce, Weissel, et al., 1989; Taylor et al., this volume; Broglia et al., this volume). This physical change is not accompanied by drastic changes in the mineralogic and chemical composition of the sediments, as is indicated by the rather con- stant calcite percentages between 200 and 330 mbsf (i.e., above and below the physical disconformity; Fig. 3). Also, silica content calculated from geochemical logging is in the same range above and below the disconformity, and there is no significant increase in ash content.

Opal-CT persists below 290 mbsf at Site 752, though at that depth the transformation from opal-A to opal-CT has taken place. The bulk density and velocity functions of depth in this carbonate 
Table 2. Elemental composition (wt \%) of selected samples (carbonate-free residues), Broken Ridge.

\begin{tabular}{|c|c|c|c|c|c|c|c|c|c|c|}
\hline $\begin{array}{l}\text { Core, section, } \\
\text { interval }(\mathrm{cm})\end{array}$ & $\begin{array}{l}\text { Depth } \\
\text { (mbsf) }\end{array}$ & Age & $\underset{(\mathrm{wt} \%)}{\mathrm{SiO}_{2}}$ & $\begin{array}{l}\mathrm{TiO}_{2} \\
\text { (wt \%) }\end{array}$ & $\begin{array}{l}\mathrm{Al}_{2} \mathrm{O}_{3} \\
(\mathrm{wt} \%)\end{array}$ & $\begin{array}{l}\mathrm{Fe}_{2} \mathrm{O}_{3} \\
(\mathrm{wt} \%)\end{array}$ & $\begin{array}{c}\mathrm{MgO} \\
\text { (wt \%) }\end{array}$ & $\underset{(w t \%)}{\mathrm{CaO}}$ & $\begin{array}{l}\mathrm{Na}_{2} \mathrm{O} \\
(\mathrm{wt} \%)\end{array}$ & $\begin{array}{c}\mathrm{K}_{2} \mathrm{O} \\
(\mathrm{wt} \%)\end{array}$ \\
\hline \multicolumn{11}{|l|}{$121-752 \mathrm{~A}-$} \\
\hline $15 X-1,55-57$ & 133 & Eocene & 98.68 & 0.12 & 1.46 & 0.52 & 0.06 & 0.38 & 0.10 & 0.14 \\
\hline $25 \mathrm{X}-1,53-55$ & 220 & late Paleocene & 74.48 & 1.07 & 7.52 & 8.60 & 3.29 & 2.99 & 0.46 & 1.40 \\
\hline $26 \times-6,70-72$ & 247 & late Paleocene & 92.27 & 0.50 & 2.50 & 2.39 & 0.54 & 1.00 & 0.28 & 0.53 \\
\hline $29 \times-4,19-21$ & 272 & late Paleocene & 91.11 & 0.81 & 2.61 & 2.71 & 0.62 & 1.30 & 0.24 & 0.55 \\
\hline $31 \times-4,9-11$ & 283 & late Paleocene & 84.87 & 1.12 & 4.12 & 4.62 & 1.45 & 2.49 & 0.28 & 0.96 \\
\hline $32 X-2,33-35$ & 290 & late Paleocene & 76.89 & 1.41 & 5.86 & 8.35 & 2.57 & 2.74 & 0.39 & 1.66 \\
\hline $32 \mathrm{X}-3,99-101$ & 292 & late Paleocene & 89.52 & 0.85 & 2.84 & 3.46 & 0.96 & 1.42 & 0.22 & 0.69 \\
\hline $33 \mathrm{X}-1,80-82$ & 299 & early Paleocene & 89.14 & 1.06 & 4.63 & 2.56 & 0.89 & 0.79 & 0.23 & 0.71 \\
\hline $33 \times-3,89-91$ & 302 & early Paleocene & 78.80 & 1.83 & 9.43 & 4.15 & 1.65 & 2.31 & 0.69 & 1.05 \\
\hline $33 \times-4,10-12$ & 303 & early Paleocene & 82.55 & 1.63 & 7.33 & 4.31 & 1.49 & 1.17 & 0.48 & 1.04 \\
\hline \multicolumn{11}{|l|}{$121-752 \mathrm{~B}-$} \\
\hline $5 R-2,71-73$ & 299 & early Paleocene & 83.19 & 1.47 & 7.00 & 3.95 & 1.45 & 1.40 & 0.49 & 1.04 \\
\hline $6 \mathrm{R}-2,88-90$ & 308 & early Paleocene & 92.04 & 0.77 & 2.74 & 2.35 & 0.71 & 0.47 & 0.17 & 0.74 \\
\hline \multicolumn{11}{|l|}{ 121-754B- } \\
\hline $5 R-2,12-14$ & 153 & early Maestrichtian & 71.82 & 1.73 & 12.87 & 5.13 & 2.11 & 1.78 & 1.00 & 3.53 \\
\hline \multicolumn{11}{|l|}{$121-754 \mathrm{~A}-$} \\
\hline $20 \mathrm{~N}-2,89-91$ & 164 & Campanian? & 74.84 & 1.85 & 12.03 & 5,32 & 3.03 & 0.88 & 0.42 & 2.10 \\
\hline $20 \mathrm{~N}-2,120-123$ & 165 & Campanian? & 72.86 & 1.43 & 11.04 & 6.35 & 2.97 & 1.09 & 0.18 & 3.12 \\
\hline \multicolumn{11}{|l|}{ 121-754B- } \\
\hline $15 R-2,92-94$ & 250 & Campanian? & 83.00 & 0.98 & 7.29 & 3.81 & 2.21 & 1.18 & 0.20 & 1.40 \\
\hline $20 \mathrm{R}-1,44-46$ & 297 & Campanian? & 89.88 & 0.42 & 3.00 & 2.45 & 2.63 & 1.04 & 0.13 & 0.54 \\
\hline $22 \mathrm{R}-1,21-23$ & 316 & Campanian? & 97.94 & 0.16 & 1.29 & 0.94 & 0.54 & 0.18 & 0.00 & 0.26 \\
\hline \multicolumn{11}{|l|}{$121-755 \mathrm{~A}-$} \\
\hline $14 \mathrm{R}-2,137-139$ & 153 & Conacian-Turonian & 75.39 & 0.75 & 6.24 & 4.48 & 1.52 & 8.07 & 1.37 & 0.68 \\
\hline
\end{tabular}

Note: $\mathrm{MnO}$ and $\mathrm{P}_{2} \mathrm{O}_{5}$ percentages are lower than $0.06 \mathrm{wt} \%$ in all residues except Sample 121-755A-14R-2, $137-139 \mathrm{~cm}$, where $\mathrm{P}_{2} \mathrm{O}_{5}$ is $0.34 \mathrm{wt} \%$.

section differ from the trends found in the opal-A-rich interval. However, the contrast of bulk density and porosity between the chalk section above $220 \mathrm{mbsf}$ and the interval below $300 \mathrm{mbsf}$ clearly illustrates that a diagenetic reaction has taken place in the lower section. The mean density and porosity of Unit D chalks are $1.81 \mathrm{~g} / \mathrm{cm}^{3}$ and $32 \%$, respectively.

The most pronounced opal-CT to quartz transition occurs at the top of Unit E, at about $380 \mathrm{mbsf}$ at Site 752 and $320 \mathrm{mbsf}$ at Site 754 (Table 1). No apparent bulk-density or porosity change is associated with this transformation. However, the velocity profile shows an increase of about $500 \mathrm{~m} / \mathrm{s}$ relative to the general velocity-depth profile developed in Units A and D.

\section{DISCUSSION}

\section{Timing of Silica Diagenesis}

One of the basic questions concerning diagenesis on Broken Ridge is whether the observed silica transformations resulted from pre-rift burial or from post-rift (= Holocene) burial. Data presented in Table 1 show a more positive correlation of silica diagenesis with age rather than with present sub-bottom depth, thus favoring a middle Eocene (and older) transformation of opal-A to authigenic opal-CT and finally to quartz. At Site 752, Holocene depth of burial is, however, only about $100 \mathrm{~m}$ shallower than pre-rift burial (Table 1). Increasing $\mathrm{SiO}_{2}$ concentrations in pore water with depth (Fig. 4) may suggest that biogenic silica is recently dissolved at depths below 180 mbsf. Silica (opal-A) that is neither affected by dissolution nor by precipitation since the middle Eocene would have led to an equilibration of $\mathrm{SiO}_{2}$ concentration in pore waters, if sufficient rates of $\mathrm{SiO}_{2}$ diffusion or pore-water convection exist. However, no indication for a decrease in pore-water $\mathrm{SiO}_{2}$ concentration as a result of opal-CT precipitation was found at greater depth. Also, the narrow transition zone between opal-A and opal-CT-bearing sediments (278299 mbsf) suggests that silica diagenesis took place at a time when the geothermal gradient was higher than at present on Broken Ridge. Usually, vertical intervals in which diagenetic reactions occur are much narrower in regions of high heat flow (Hein et al., 1983) than in areas of low heat flow, as is well established for the petroleum generation process (Yalcin and Welte, 1988). Also, the relatively shallow depth at which the opal-A to opal-CT transformation occurred (even if a maximum preburial depth is assumed) is indicative of a higher than present heat flow. Isaacs et al. (1983) described opal-CT rocks that become abundant at 750 to $1100 \mathrm{~m}$ depth, corresponding to $40^{\circ}-50^{\circ} \mathrm{C}$ in the Miocene Monterey Formation in California, which is much deeper than on Broken Ridge. The increase in diatom fragmentation (Table 4) from 240 to 280 mbsf at Site 752 indicates that a 40 -m-thick section of enhanced silica dissolution overlies the silica precipitation interval below 280 mbsf.

Final proof for the timing of silica diagenesis could be achieved by drilling a deep hole at Site 753 (see Fig. 1). If silica diagenesis is an ongoing process on Broken Ridge, opal-CT would be expected at about $300 \mathrm{mbsf}$ instead of $400-500 \mathrm{mbsf}$, namely in the same stratigraphic section as at Site $\mathbf{7 5 2}$. 
Table 3. Calculated percentages of biogenic and nonbiogenic silica in selected samples.

\begin{tabular}{|c|c|c|c|}
\hline $\begin{array}{l}\text { Core, section, } \\
\text { interval }(\mathrm{cm})\end{array}$ & $\begin{array}{l}\mathrm{SiO}_{2} \\
(\%)\end{array}$ & $\begin{array}{c}\text { Nonbiogenic silica } \\
(\%)\end{array}$ & $\begin{array}{c}\text { Biogenic silica } \\
(\%)\end{array}$ \\
\hline \multicolumn{4}{|l|}{$121-752 \mathrm{~A}-$} \\
\hline $15 X-1,55-57$ & 98.7 & 3.4 & 95.3 \\
\hline $25 \mathrm{X}-1,53-55$ & 74.5 & 22.6 & 51.9 \\
\hline $26 \mathrm{X}-6,70-72$ & 92.27 & 5.87 & 86.40 \\
\hline $29 \times-4,19-21$ & 91.11 & 6.17 & 84.94 \\
\hline $31 \times-4,9-11$ & 84.87 & 10.47 & 74.40 \\
\hline $32 X-2,33-35$ & 76.89 & 16.64 & 60.23 \\
\hline $32 \times-3,99-101$ & 89.52 & 6.96 & 82.56 \\
\hline $33 \mathrm{X}-1,80-82$ & 89.14 & 11.00 & 78.14 \\
\hline $33 \mathrm{X}-3,89-91$ & 78.80 & 22.94 & 55.86 \\
\hline $33 \times-4,10-12$ & 82.55 & 17.88 & 64.67 \\
\hline \multicolumn{4}{|l|}{$121-752 \mathrm{~B}-$} \\
\hline $5 R-2,71-73$ & 83.19 & 17.07 & 66.12 \\
\hline $6 \mathrm{R}-2,88-90$ & 92.04 & 6.52 & 85.52 \\
\hline \multicolumn{4}{|l|}{$121-754 \mathrm{~B}-$} \\
\hline $5 R-2,12-14$ & 71.8 & 31.7 & 40.1 \\
\hline \multicolumn{4}{|l|}{$121-754 \mathrm{~A}-$} \\
\hline $20 \mathrm{~N}-2,89-91$ & 74.5 & 32.1 & 42.4 \\
\hline $20 \mathrm{~N}-2,120-123$ & 72.9 & 29.7 & 43.2 \\
\hline \multicolumn{4}{|l|}{$121-754 \mathrm{~B}-$} \\
\hline $15 \mathrm{R}-2,92-94$ & 83.0 & 17.8 & 65.2 \\
\hline $20 \mathrm{R}-1,44-46$ & 89.9 & 10.3 & 79.6 \\
\hline $22 \mathrm{R}-1,21-23$ & 97.9 & 3.1 & 94.8 \\
\hline \multicolumn{4}{|l|}{$121-755 \mathrm{~A}-$} \\
\hline $14 \mathrm{R}-2,137-139$ & 75.4 & 15.5 & 59.9 \\
\hline
\end{tabular}

Note: Percentages calculated using the normative equation of Leinen (1977).

\section{Source of Authigenic Silica}

Based on the elemental composition of carbonate-free residues and following the calculation of Leinen (1977), authigenic silica on Broken Ridge is mainly derived from biogenic opal-A (Tables 2 and 3 ).

Furthermore, diatoms and radiolarians that commonly occur in the Paleocene sediments of Hole 752A are not found below the approximate depth of 295-296 mbsf. This transition is relatively abrupt. The interval between 250 and 295 mbsf shows a noticeable deterioration of assemblage preservation, and, in addition, a short interval around $279 \mathrm{mbsf}$ is barren of siliceous microfossils. This latter interval corresponds to the first occurrence of opal-CT. The deterioration of preservation is recorded by the lower diversity of the diatom assemblages and increasing abundance of dissolutionresistant species. There is a direct correlation between the decrease of biogenic silica and degree of preservation. There is no evidence that ash is a major component of the carbonate-free fraction in samples with lower abundances of biogenic remains (poorly preserved samples). Furthermore, high ash content was commonly found associated with relatively well-preserved assemblages, and the barren samples below 295 mbsf also contain little or no ash.

In samples recorded as barren of siliceous microfossils (below 295 mbsf and at about 279 mbsf at Site 752), large siliceous accumulations were observed that might be the product of diatom or radiolarian recrystallization. In the best example (between 297 and $302 \mathrm{mbsf}$ ), some of the original structure of the microfossils are preserved (see PI. 1, Fig. 3) and indicate an in-situ replacement of opal-A (Murata et al., 1977; von Rad et al., 1977; Hein et al., 1978). Below 303 mbsf, silica spheres without any biological structure are also present in the samples. These lepispheres are interpreted to be derived from precipitation of opal-CT in the pores and have a strong impact on lithification (Riech and von Rad, 1979). In addition, phillipsite and clay minerals were also formed during that stage (Pl. 1, Fig. 5, and Pl. 2, Fig. 4).

\section{Effects of Chemical Environment}

On Broken Ridge, the transition of biogenic opal-A into authigenic silica (quartz or opal-CT) occurs in carbonates that contain only limited amounts of silica. According to Lancelot (1973), carbonates rarely contain porcellanite (composed of opal-CT), because opal-A is directly transformed into quartz in this type of environment. This is explained by the absence of "foreign cations" in carbonates which fit into the opal-CT lattice and which are probably a necessary prerequisite for opal-CT formation (see Flörke, 1955; Millot, 1964).

At Site 752, biogenic opal-A is transformed into opal-CT in sediments that contain $80 \%$ calcite on an average. There is no evidence for a direct transformation of opal-A into quartz (Fig. 2). Furthermore, the youngest samples with quartz as the major silica phase are not particularly enriched in carbonate (Table 1). Based on these observations, we conclude that carbonate content is not critical for opal-A transformation on Broken Ridge and that it may become critical only if carbonate contents exceed $85 \%$ (see von Rad et al., 1977, for more detailed discussion).

At Site 752 , there is a 20 -m-thick silica transition zone between 278 and 299 mbsf. In all samples above 278 mbsf, opal-A is the major silica phase, whereas below 299 mbsf authigenic silica predominates (Table 1). Between these two depths, the first porcellanite layer occurs at $280 \mathrm{mbsf}$. In view of the general similarity of opal-A- and opal-CT-bearing samples, with respect to carbonate content and general lithologic character, we presently have no key to the local conditions responsible for the respective dominance of either opal-A or opal-CT in this interval. However, the major factors responsible for the opal-A to opal-CT transformation obviously are temperature and time.

Samples that were more deeply buried prior to rifting were affected by an ordering of the opal-CT lattice (compare Figs. 2C and 2D) and crystallization of quartz (Fig. 2E). Quartz is present in all Campanian and older sediments on Broken Ridge (Table 2). Authigenesis of quartz is evident from the occurrence of chert fragments and layers below $350 \mathrm{mbsf}$ (just above the Cretaceous/Tertiary boundary) at Site 752 and in older sediments at Site 754 (Peirce, Weissel, et al., 1989). On the other hand, opalCT is still present in the middle Cretaceous sediments at Site 755 as apparent from X-ray data (Table 1) and the occurrence of porcellanite (Peirce, Weissel, et al., 1989). Because of the co-occurrence of opal-CT and quartz over an interval of at least $750 \mathrm{~m}$ of pre-rift stratigraphic depth, the transformation of opal-CT into quartz is not only dependent on time and temperature, but also on local conditions such as the type of opal-CT (see Murata et al., 1977; von Rad et al., 1977; Williams and Crerar, 1985) and the pore-water chemistry. The influence of temperature and time is, however, evident from the general increase of the quartz/opal-CT ratio with increased pre-rift burial depth and age within this section (see Table 1).

\section{Lithification}

At Site 752, a change in several physical properties occurs at the top of the opal-CT dominated sediments, (i.e., at about 290 mbsf). Our data indicate that the cementation of primary grains by newly formed opal-CT is the primary cause for these changes (see Fig. 3; Riech and von Rad, 1979). Dissolution of porous opal-A (Pl. 1, Figs. 1 and 2 ) and cementation of pre-existing and 
Table 4. Summary of the diatom preservation (dissolution and fragmentation) at Hole 752A. ${ }^{\mathrm{a}}$

\begin{tabular}{|c|c|c|c|c|c|c|c|}
\hline $\begin{array}{l}\text { Core, section, } \\
\text { interval }(\mathrm{cm})\end{array}$ & $\begin{array}{l}\text { Depth } \\
\text { (mbsf) }\end{array}$ & $\begin{array}{l}\text { Diatom } \\
\text { preservation }\end{array}$ & $\begin{array}{c}\text { Whole diatoms/ } \\
\text { diatom fragments } \\
(\%)\end{array}$ & $\begin{array}{c}\text { Biogenic } \\
\text { compounds } \\
\text { (approx. \%) }\end{array}$ & $\begin{array}{l}\text { Recrystallized } \\
\text { biologic } \\
\text { remains }{ }^{c}\end{array}$ & $\begin{array}{c}\text { Ash } \\
\text { occurrence }^{\mathrm{d}}\end{array}$ & 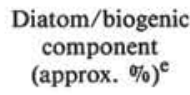 \\
\hline \multicolumn{8}{|l|}{$121-752 \mathrm{~A}-$} \\
\hline $22 X-1,55-57$ & 200.65 & $\mathrm{M}$ & 10.50 & 80.00 & & - & 0.50 \\
\hline $23 \mathrm{X}-1,44-46$ & 210.23 & G (M) & 4.50 & 90.00 & & - & 0.75 \\
\hline $24 \mathrm{X}-1,55-57$ & 220.05 & G & 22.50 & 90.00 & & + & 0.90 \\
\hline $25 \mathrm{X}-1,51-53$ & 229.63 & G & 17.00 & 80.00 & & ++ & 0.75 \\
\hline $25 \mathrm{X}-3,51-53$ & 232.61 & G & 8.00 & 80.00 & & +++ & 0.75 \\
\hline $26 \mathrm{X}-1,55-57$ & 239.35 & G & 11.00 & 95.00 & & + & 0.90 \\
\hline $26 \mathrm{X}-4,101-102$ & 244.30 & M & 11.00 & 90.00 & & ++ & 0.75 \\
\hline $27 \mathrm{X}-1,50-52$ & 248.90 & M & 9.00 & 90.00 & & + & 0.90 \\
\hline $27 X-4,50-52$ & 253.40 & $\mathrm{P}$ & 5.00 & 90.00 & + & + & 0.90 \\
\hline $28 \mathrm{X}-1,55-57$ & 258.65 & $P$ & 7.50 & 75.00 & & + & 0.75 \\
\hline $28 X-4,100-102$ & 263.60 & $\mathbf{P}$ & 5.00 & 80.00 & & + & 0.80 \\
\hline $29 \mathrm{X}-1,55-57$ & 268.25 & $\mathbf{P}$ & 7.00 & 75.00 & & + & 0.75 \\
\hline $29 \mathrm{X}-2,100-102$ & 270.20 & $\mathbf{P}$ & 1.50 & 75.00 & & + & 0.90 \\
\hline $29 \mathrm{X}-3,55-57$ & 271.25 & M & 8.00 & 90.00 & & ++ & 0.90 \\
\hline $29 \mathrm{X}-4,100-102$ & 273.20 & $P$ & 4.00 & 75.00 & & + & 0.90 \\
\hline $29 \times-5,55-57$ & 274.25 & M & 6.50 & 90.00 & & ++ & 0.90 \\
\hline $29 \mathrm{X}-6,100-102$ & 276.20 & $\mathbf{P}$ & 1.50 & 75.00 & & + & 0.50 \\
\hline $29 \times-7,25-27$ & 276.95 & $\mathrm{M}(\mathrm{P})$ & 4.50 & 80.00 & & + & 0.75 \\
\hline $30 \times-1,54-56$ & 277.94 & $\mathrm{M}(\mathrm{P})$ & 3.50 & 80.00 & & + & 0.75 \\
\hline $30 \mathrm{X}-\mathrm{CC}$ & 278.90 & barren & & & + & $?$ & \\
\hline $31 X-1,55-57$ & 279.95 & barren & & & + & - & \\
\hline $31 \times-2,100-102$ & 281.90 & $\mathbf{P}$ & 1.50 & 50.00 & & + & 0.50 \\
\hline $31 X-3,55-57$ & 282.95 & P & 2.50 & 90.00 & & + & 0.60 \\
\hline $31 X-4,100-102$ & 284.90 & P & 1.50 & 50.00 & & + & 0.25 \\
\hline $31 X-5,55-57$ & 285.95 & $\mathbf{P}$ & 4.00 & 90.00 & & + & 0.75 \\
\hline $31 X-6,50-52$ & 287.40 & $\mathbf{P}$ & 4.50 & 75.00 & & + & 0.50 \\
\hline $31-\mathrm{CC}$ & 287.94 & $\mathbf{P}$ & 4.00 & 75.00 & & + & 0.75 \\
\hline $32 X-1,55-57$ & 289.25 & $\mathrm{P}$ & 2.50 & 75.00 & & + & 0.60 \\
\hline $32 X-2,100-102$ & 291.20 & P & 2.00 & 75.00 & & + & 0.75 \\
\hline $32 X-3,55-57$ & 292.25 & $\mathrm{P}$ & 5.00 & 75.00 & & + & 0.75 \\
\hline $32 X-4,102-104$ & 294.22 & $P$ & 2.00 & 75.00 & & ++ & 0.75 \\
\hline $32 X-5,55-57$ & 295.25 & $\mathrm{P}$ & 2.00 & 60.00 & & - & 0.50 \\
\hline $32 X-6,110-112$ & 297.30 & barren & - & 50.00 & ++ & - & \\
\hline $32 X-7,14-16$ & 297.84 & barren & - & 25.00 & ++ & + & \\
\hline $32 \mathrm{X}-\mathrm{CC}$ & 298.40 & barren & - & 25.00 & ++ & - & \\
\hline $33 \mathrm{X}-2,100-102$ & 300.90 & barren & - & 25.00 & ++ & - & \\
\hline $33 \times-3,60-63$ & 302.00 & barren & - & 25.00 & ++ & - & \\
\hline $33 \mathrm{X}-4,51-53$ & 303.41 & barren & - & - & + & - & \\
\hline $33 \mathrm{X}-\mathrm{CC}$ & 304.03 & barren & - & - & + & ? & \\
\hline
\end{tabular}

Note: Data are based on observation of the carbonate-free residues under the light microscope.

${ }^{a}$ For 39 samples between 200 and 304 mbsf, with occurrence and abundance of accompanying siliceous biological remains and ashes.

${ }^{b} \mathrm{G}=$ good; $\mathrm{M}=$ moderate $\mathrm{G}(\mathrm{M})=$ good to moderate; $\mathrm{M}(\mathrm{G})=$ moderate to good; $\mathrm{P}=$ poor; $\mathrm{M}(\mathrm{P})=$ moderate to poor.

$c++=$ original structure preserved; $+=$ original structure not preserved.

$\mathrm{d}_{-}=$absent or rare; $+=$few; $++=$common; $+++=$abundant

e Total biogenic components are mostly diatoms and radiolarians.

newly formed pores by opal-CT and zeolites (Pl. 1, Figs. 3-5, and PI. 2, Figs. 2-4) seems to be responsible for the change in physical properties. Further effects on the physical properties arose from calcite recrystallization (Pl. 2, Fig. 1). Within Unit C (see Fig. 1B), chalk appears to have undergone a high degree of cementation, creating the sharp contrast in physical properties and giving rise to a seismic reflector at about $300 \mathrm{mbsf}$.

The opal-CT to quartz transition (top of Unit E) is not associated with bulk-density or porosity changes. However, the velocity profile shows an increase of about $500 \mathrm{~m} / \mathrm{s}$ relative to the general velocity-depth profile developed in Units A and D. Seismic records from this area contain a reflector that we have correlated with the porcellanite to chert and chalk to limestone transition at 380 mbsf. Changes in the physical properties of the consolidating calcareous sequence below this depth are attributed to variable amounts of ash and chert in the calcareous section. The interval from 470 to $495 \mathrm{mbsf}$ is ash-rich, resulting in slightly lower bulk density and clearly lower velocity, as also recorded for the ashrich interval overlying the Cretaceous/Tertiary boundary at 345365 mbsf. Dolomite and chert stringers below 525 mbsf give rise to high velocities and bulk densities in the lowermost sampled sediments.

\section{CONCLUSIONS}

Silica diagenesis at Broken Ridge has affected sediments below an approximate depth of $400 \mathrm{mbsf}$ prior to the middle Eocene rifting event. The major or exclusive source for authigenic opal-CT and quartz is biogenic silica mainly derived from diatoms and radiolarians. The transition zone from sediments containing exclusively opal-A as the silica phase to sediments with opal-CT as the predominant silica mineral is only $20 \mathrm{~m}$ thick, indicating that local variations in sediment and pore-water chemistry are of only minor importance for this phase transformation. Precipitation of opal-CT in the pore spaces of the sediment increased lithification and caused marked changes in the physical properties. At greater pre-rift stratigraphic depths, both quartz and opalCT are present over an interval of at least $750 \mathrm{~m}$. Within this section, a general increase in the quartz/opal-CT ratio and better crystallinity of opal-CT are observed with increasing pre-rift stratigraphic depth, indicating that temperature and time are 

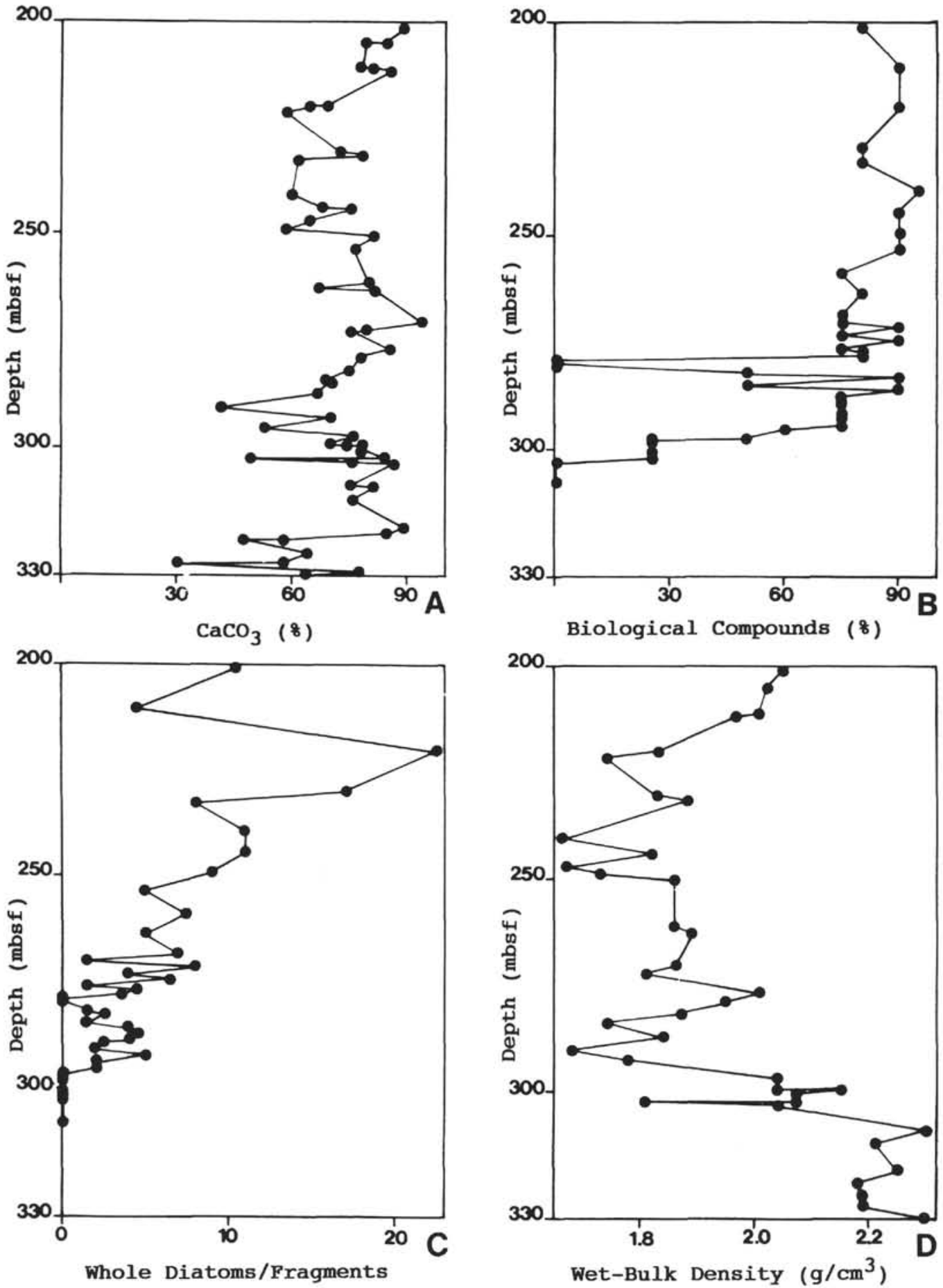

Figure 3. A. Depth plots of carbonate content (see Littke et al., this volume). B. Percentage of biologic compounds. C. Ratio of whole diatoms to diatom fragments, both determined on carbonate-free residues in transmitted light. D. Wet-bulk density (see Taylor et al., this volume) at Site 752 . Note that the first peak in wet-bulk density at $280 \mathrm{mbsf}$ corresponds to the first disappearance of biologic compounds (biogenic opal-A) and to the first occurrence of opal-CT (Table 1).

among the factors responsible for the diagenetic evolution of authigenic silica.

\section{ACKNOWLEDGMENTS}

We thank the Ocean Drilling Program for providing excellent study material and a unique forum for interdisciplinary scientific work. R. L. wants to thank Prof. D. H. Welte for ongoing encour- agement and advice, and the Bundesanstalt für Geowissenschaften und Rohstoffe, Hannover, and the Deutsche Forschungsgemeinschaft, Bonn, for technical and financial support (grant no. WE 346/27). E. T. acknowledges financial help from the U. S. Scientific Advisory Program. Technical support by R. Oscarson (USGS, SEM studies), Dr. C. Freiburg (KFA, XRD and XRF), S. de Waal (KFA, silica concentration), and M. Sostmann (KFA, 


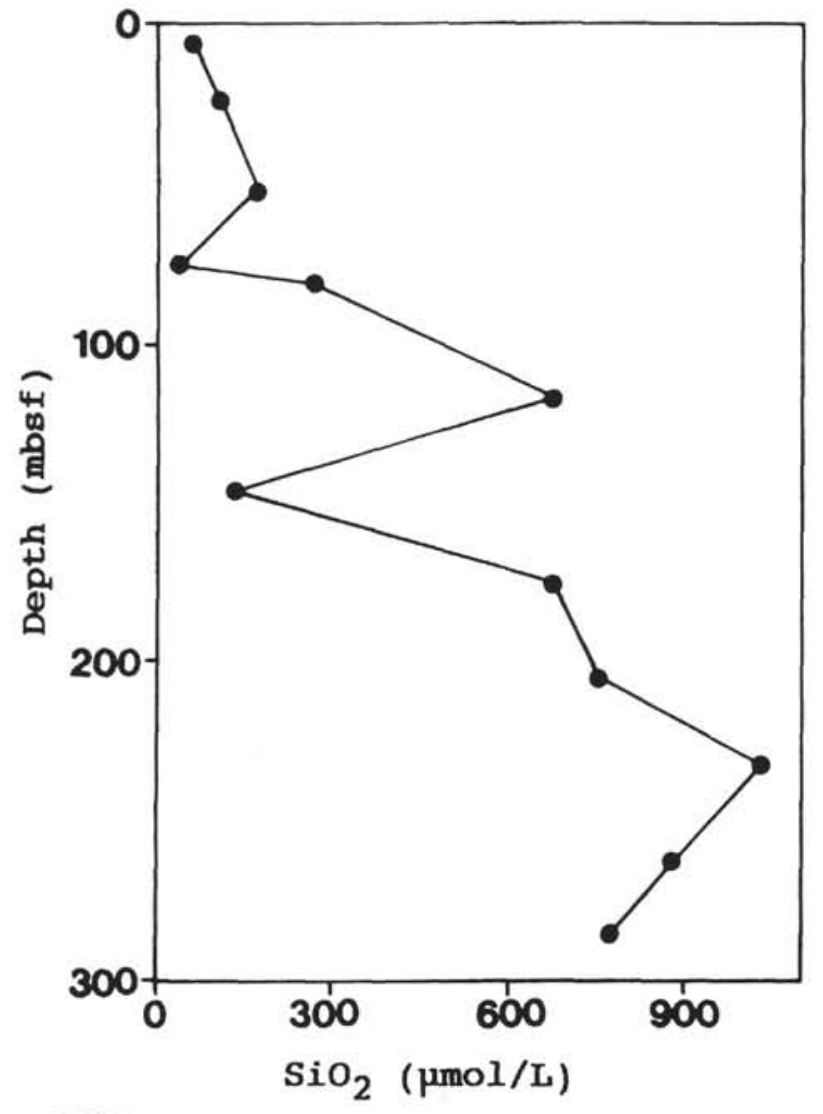

Figure 4. $\mathrm{SiO}_{2}$ concentration in pore water at Site 752 .

typing) is gratefully acknowledged. We thank Drs. J. R. Hein, U. Mann, J. Weissel, and R. H. Wilkens for critical comments that helped improve this manuscript.

\section{REFERENCES}

Calvert, S. E., 1974. Deposition and diagenesis of silica in marine sediments. In Hsü, K. J., and Jenkyns, H. C. (Eds.), Pelagic Sediments: On Land and Under the Sea. Spec. Publ. Int. Assoc. Sedimentol., 1:273-299.

Flörke, O. W., 1955. Zur Frage des "Hoch"-Cristobalit in Opalen, Bentoniten und Gläsern. Neues Jahrb. Mineral. Monatsh., 10:217223.

Hamilton, E. L., 1976. Variations in density and porosity with depth in deep-sea sediments. J. Sediment. Petrol., 46:280-300.

Hein, J. R., Sancetta, C., and Morgenson, L. A., 1983. Petrology and geochemistry of silicified upper Miocene chalk, Costa Rica rift, Deep Sea Drilling Project Leg 69. In Cann, J. R., Langseth, M. G., Honnorez, J., Von Herzen, R. P., White, S. M., et al., Init. Repts. DSDP, 69: Washington (U.S. Govt. Printing Office), 395-409.
Hein, J. R., Scholl, D. W., Barron, J. A., Jones, M. G., and Miller, J., 1978. Diagenesis of late Cenozoic diatomaceous deposits and formation of the bottom simulating reflector in the southern Bering Sea. Sedimentology, 25:155-181.

Isaacs, C. M, Pisciotto, K. A., and Garrison, R. E., 1983. Facies and diagenesis of the Miocene Monterey Formation, California: a summary. In Iijima, A., Hein, J. R., and Siever, R. (Eds.), Siliceous Deposits in the Pacific Region. Dev. in Sedimentol., 36:247-282.

Jones, J. B., and Segnit, E. R., 1971. The nature of opal. I. Nomenclature and constituent phases. J. Geol. Soc. Aust., 18/1:57-68.

Lancelot, Y., 1973. Chert and silica diagenesis in sediments from the central Pacific. In Winterer, E. L., Ewing, J. I., et al. Init. Repts. DSDP, 17: Washington (U.S. Govt. Printing Office), 377-405.

Langer, K., and Flörke, O. W., 1974. Near infrared absorption spectra (4000-9000 cm $\mathrm{cm}^{-1}$ ) of opals and the role of "water" in these $\mathrm{SiO}_{2} \mathrm{nH}_{2} \mathrm{O}$ minerals. Fortschr. Mineral., 52:17-51.

Leinen, M., 1977. A normative calculation technique for determining opal in deep-sea sediments. Geochim. Cosmochim. Acta, 41:671-676.

Mahmood, K., 1990. Porosity gradients in marine sediments [M.S. thesis]. Texas A\&M Univ., College Station, TX.

Mann, U., and Müller, G., 1985. Early diagenesis of biogenic siliceous constituents in silty clays and claystones, Japan Trench. Neues. Jahrb. Mineral. Abh., 153:33-57.

Martin, J. H., and Knauer, G. A., 1973. The elemental composition of plankton. Geochim. Cosmochim. Acta, 37:1639-1653.

Mikkelsen, N., 1980. Experimental dissolution of Pliocene diatoms. Nova Hedwigia Beih., 33:893-911.

Millot, G., 1964. Géologie des Argiles: Paris (Masson).

Murata, K. J., Friedman, I., and Gleason, J. D., 1977. Oxygen isotope relations between diagenetic silica minerals in Monterey Shale, Temblor Range, California. Am. J. Sci., 277:259-272.

Peirce, J., Weissel, J., et al., 1989. Proc. ODP, Init. Repts., 121: College Station, TX (Ocean Drilling Program).

Riech, V., and von Rad, U., 1979. Eocene porcellanites and early Cretaceous cherts from the Western North Atlantic. In Tucholke, B. E., Vogt, P. R., et al., Init. Repts. DSDP, 43: Washington (U.S. Govt. Printing Office), 437-448.

Thurow, J., 1988. Diagenetic history of Cretaceous radiolarians, North Atlantic Ocean (ODP Leg 103 and DSDP Holes 398D and 603B). In Boillot, G., Winterer, E. L., et al., Proc. ODP, Sci. Results, 103: College Station, TX (Ocean Drilling Program), 531-555.

von Rad, U., Riech, V., and Rösch, H., 1977. Silica diagenesis in continental margin sediments off northwest Africa. In Lancelot, Y., and Seibold, E., et al., Init. Repts. DSDP, 41: Washington (U.S. Govt. Printing Office), 879-905.

Williams, L. A., and Crerar, D. A., 1985. Silica diagenesis, II. General mechanisms. J. Sediment. Petrol., 55:313-321.

Williams, L. A., Parks, G. A., and Crerar, D. A., 1985. Silica diagenesis, I. Solubility controls. J. Sediment. Petrol., 55:301-311.

Yalcin, M. N., and Welte, D. H., 1988. The thermal evolution of sedimentary basins and significance for hydrocarbon generation. Bull. Turk. Assoc. Petr. Geol., 1:12-26.

Date of initial receipt: 11 May 1990

Date of acceptance: 4 October 1990

Ms 121B-179 


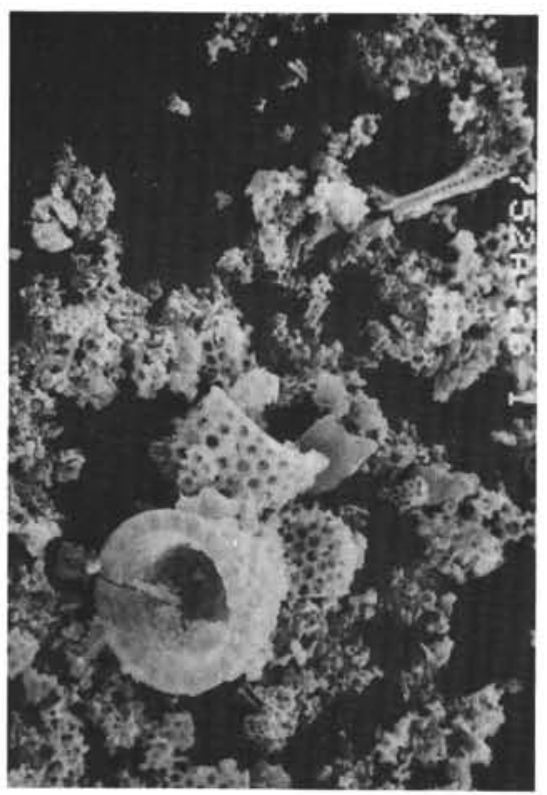

1

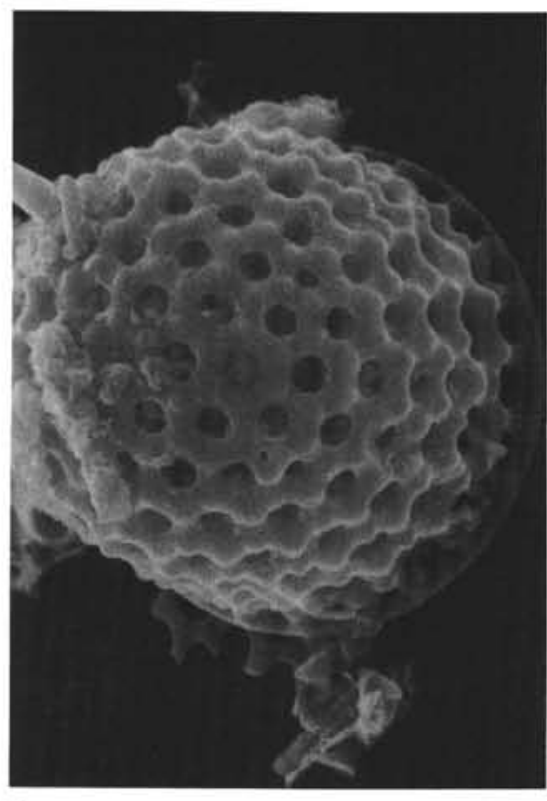

2

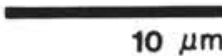

$10 \mu \mathrm{m}$

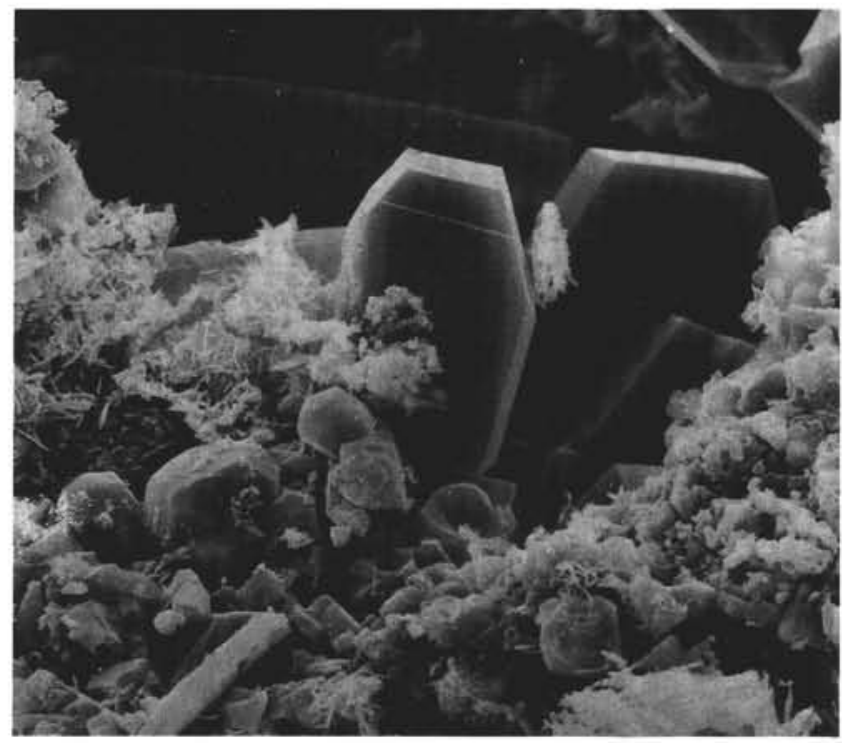

5

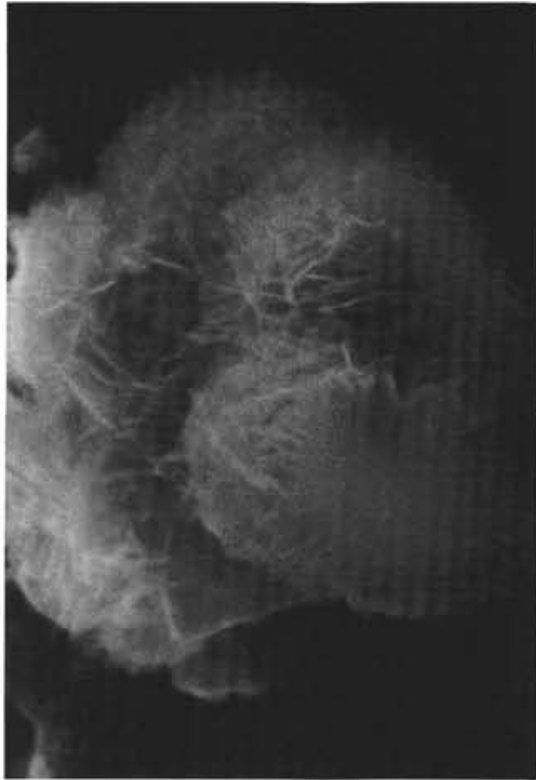

3

$4 \mu \mathrm{m}$

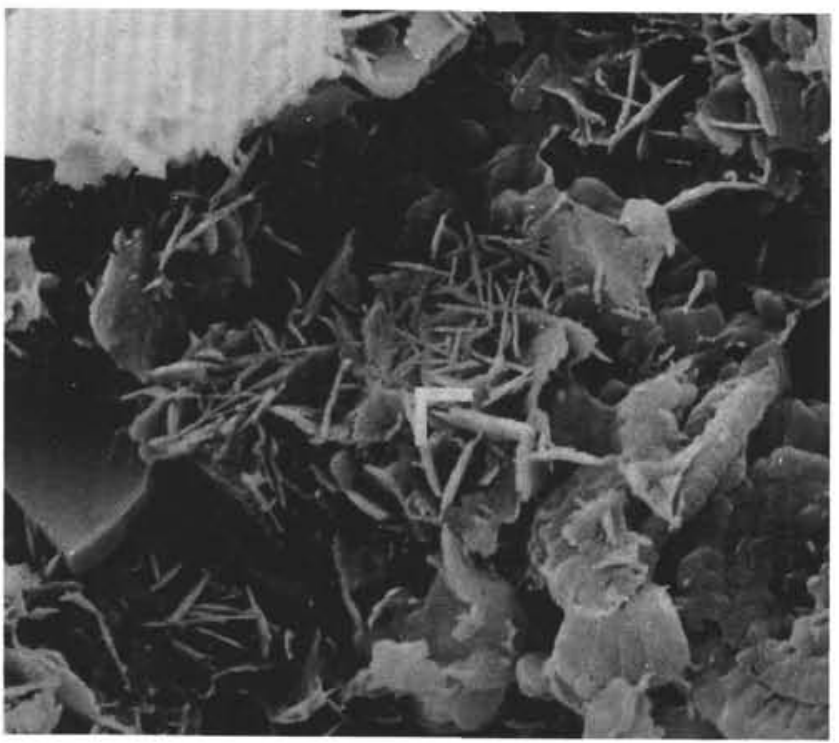

4

$10 \mu \mathrm{m}$

Plate 1. SEM photomicrographs. 1. Typical carbonate-free residue with well- to moderately preserved biogenic compounds. Sample $121-752 \mathrm{~A}-26 \mathrm{X}-1,55-57 \mathrm{~cm}$. 2. Stephanopyxis turris, one of the coarse diatoms still preserved directly above the opal-A/opal-CT transition zone. Residue of Sample 121-752A-26X-1, 55-57 $\mathrm{cm}$. 3. Recrystallized former diatom (?). Residue of Sample 121-752A-32X-7, 14-16 cm. 4. Opal-CT blades in carbonate matrix. Lack of alumina, according to EDAX data, reveals the silica nature of the blades. Sample 121-752A-33X-1, 80-82 cm. 5. Large phillipsite crystal and opal-CT blades surrounded by blocky micrite. Sample 121-752A-33X-1, 80-82 cm. 


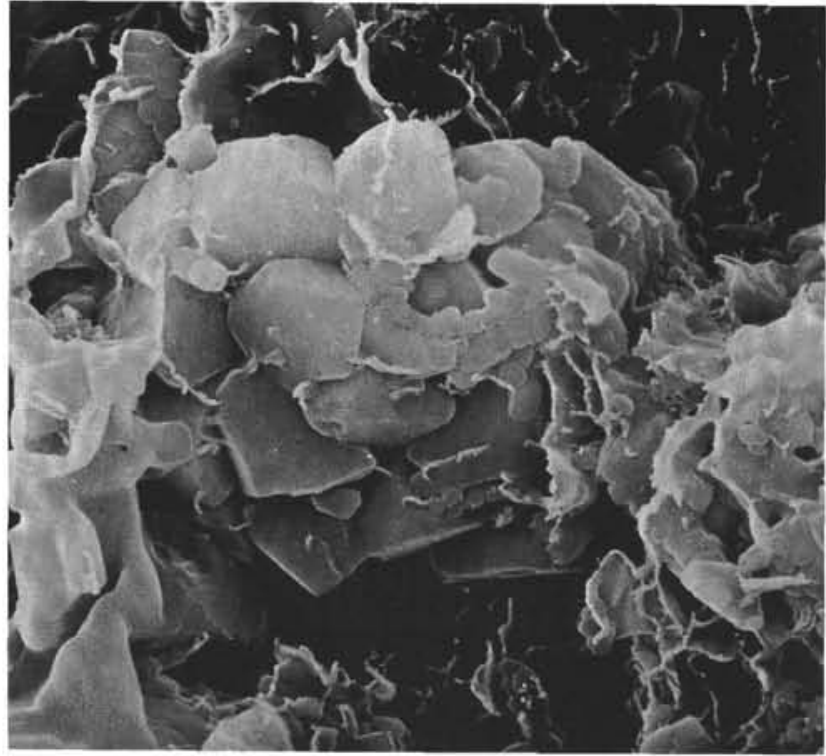

1

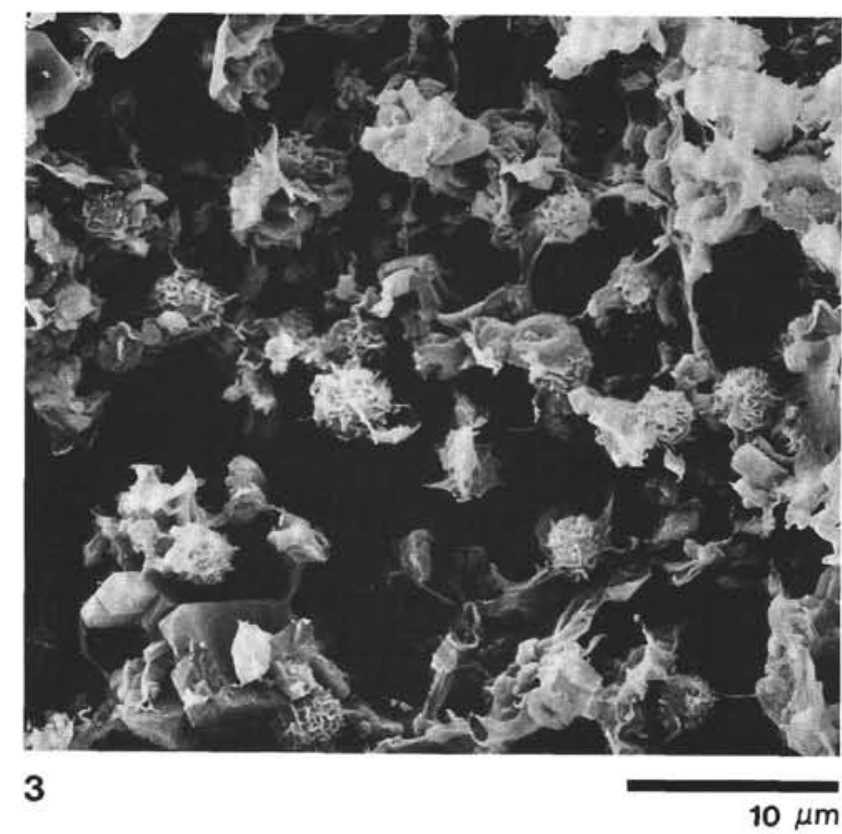

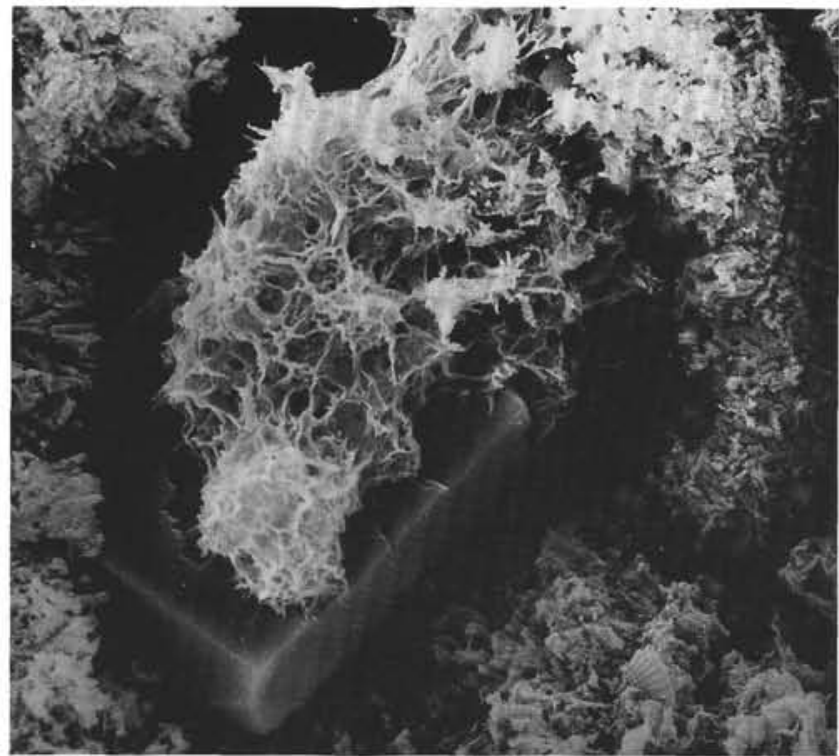

2

$10 \mu \mathrm{m}$

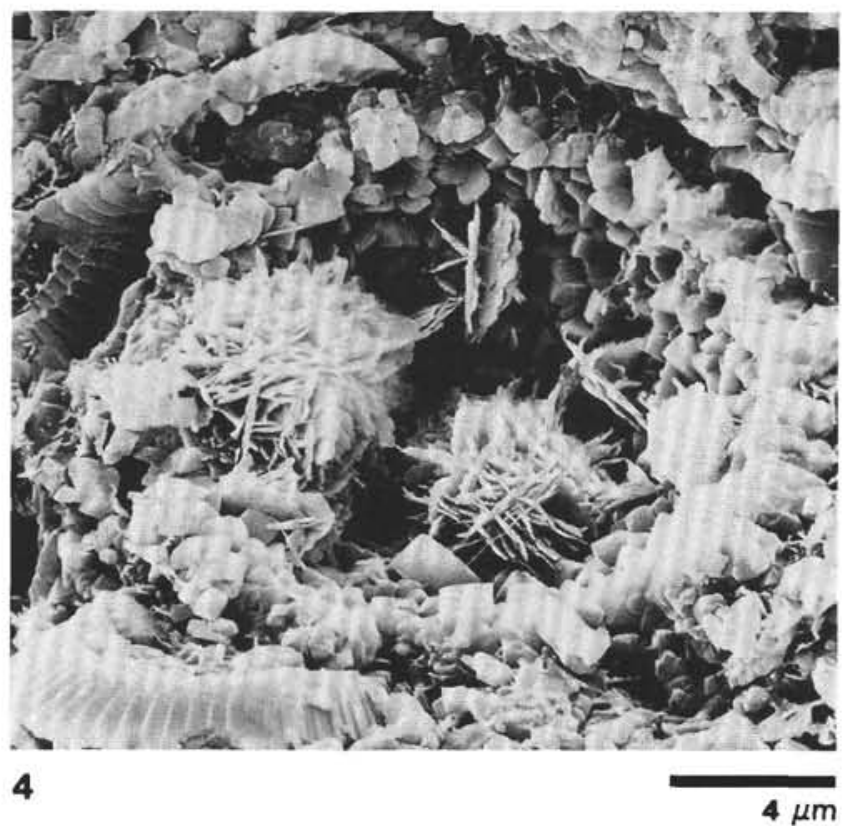

Plate 2. SEM photomicrographs. 1. Diagenetically formed calcite micrite (recrystallized coccolith plates). Sample 121-752A-33X-1, 80-82 cm. 2. Phillipsite crystal overgrown by smectite. Sample 121-752A-33X-3, 89-91 cm. 3. Overview of opal-CT lepispheres and phillipsite in Sample 121-752B-5R-2, 71-73 cm. 4. Opal-CT blades forming lepispheres in a foraminifer (?) chamber. Sample 121-752B-6R-2, 88-90 cm. 